\title{
New Evidence for Bottlenose Dolphin (Tursiops spp.) Population Connectivity between Kangaroo Island and South Australian Mainland Waters
}

\author{
Nardi Cribb1, Phyll Bartram², Tony Bartram ${ }^{2}$, Laurent Seuront ${ }^{* *}$ \\ ${ }^{1}$ School of Biological Sciences, Flinders University, Adelaide, Australia \\ ${ }^{2}$ Kangaroo Island/Victor Harbor Dolphin Watch, Kangaroo Island, Australia \\ Email: *laurent.seuront@cnrs.fr
}

How to cite this paper: Cribb, N., Bartram, P., Bartram, T. and Seuront, L. (2018) New Evidence for Bottlenose Dolphin (Tursiops spp.) Population Connectivity between Kangaroo Island and South Australian Mainland Waters. Open Journal of Marine Science, 8, 38-50.

https://doi.org/10.4236/ojms.2018.81003

Received: October 16, 2017

Accepted: January 7, 2018

Published: January 10, 2018

Copyright $\odot 2018$ by authors and Scientific Research Publishing Inc. This work is licensed under the Creative Commons Attribution International License (CC BY 4.0).

http://creativecommons.org/licenses/by/4.0/

Open Access

\begin{abstract}
Limited information still exists on the movements of bottlenose dolphins in South Australian coastal waters. There is, however, a need to overcome this paucity of information for an effective development and implementation of conservation and management initiatives in these waters that are increasingly threatened by anthropogenic activities. This study infers potential movements of bottlenose dolphins (Tursiops spp.) between Kangaroo Island that separate and shelter South Australian coastal waters from the Southern Ocean swell, and the South Australian mainland (The Fleurieu Peninsula and The Adelaide Dolphin Sanctuary). Bottlenose dolphins were identified from three separate photo-identification catalogues collated from around the South Australian coastline. Of the 3518, 654 and 181 dolphins sighted in Kangaroo Island, Fleurieu Peninsula and the Adelaide Dolphin Sanctuary, 233, 74 and 40 individuals were recognizable, respectively. Resighting rates were similar in Kangaroo Island (70.4\%) and Fleurieu Peninsula (75.7\%), but much lower in the Adelaide Dolphin Sanctuary (35\%). Ten individuals were resighted between Kangaroo Island and the Fleurieu Peninsula, whilst no matches were made between these two locations and the Adelaide Dolphin Sanctuary catalogue. This suggests a longitudinal connectivity between Kangaroo Island and South Australian mainland waters, but a lack of latitudinal connectivity that may result from the physical stratification processes that separate northern and southern South Australian waters. Our results also demonstrate the highly mobile nature of this species within South Australian waters as well as establish
\end{abstract}

"Present Address: CNRS, Univ. Lille, Univ. Littoral Côte d'Opale, UMR 8187, LOG, Laboratoired' Océanologie et de Géosciences, Wimereux, France 
photo-identification as an effective non-invasive tool in which to monitor long-term movement patterns).

\section{Keywords}

Bottlenose Dolphin, Habitat, South Australia, Connectivity, Conservation

\section{Introduction}

Bottlenose dolphins (Tursiops spp.) are found globally throughout temperate and tropical seas, and are frequently observed in shallow coastal habitats as well as offshore oceanic waters [1]. This species is commonly occurring in South Australian waters [2] [3] [4]. Baseline information regarding the ecology, distribution and movements on this species and the potential connectivity between local populations in this region is, however, still very limited, with most information based upon stranding records [2] [3]. However, previous studies have provided evidence of bottlenose dolphins occurring within both Spencer and Gulf St. Vincent as well as in the vicinity of Adelaide [5] [6] [7] and in particular the Port River-Barker Inlet estuary (The Adelaide Dolphin Sanctuary) where they are known to be resident all year round [4] [5].

Information on the movements of individuals between populations is crucial to the understanding of their space-time preference and use of specific locations [4]. Providing evidence of such movements and the use of specific locations is therefore the first stage in establishing and implementing effective management strategies [8]. This issue is particularly relevant for South Australian waters with the ever increasing range of human impacts in this region, for example, habitat degradation, coastal and industrial development, aquaculture, fisheries, intentional killings and pollution [5] [9]. This is even more of a concern for bottlenose dolphins, which are still relatively unknown in terms of demography, ecology, home range, site fidelity, residency and behavior outside the Port RiverBarker Inlet estuary in particular and in South Australian waters in general. This situation hinders assessment of their conservation status and informed decisionmaking concerning their management. In addition, the wide and coastal distribution of bottlenose dolphins, together with their vague population units potentially exposes them to a wider variety of threats and makes them more vulnerable.

The recognition of animals from naturally occurring markings is an important tool for the study of animal populations and their movements [10]. In particular, this technique has been applied to examine the ecology, behavior and movement patterns of cetaceans [11] [12]. More specifically, the application of this technique has provided insight into the movements and distribution of bottlenose dolphins in numerous locations at the global scale [4] [13] [14] [15]. Photoidentification of bottlenose dolphins is used to identify individuals non-invasively by using distinctive dorsal fin features, for example nicks and notches present on 
both the trailing and leading edges of the fin and tip [16] [17]. It is cost-effective, can benefit from citizen science approaches and also has the great advantage of avoiding physical capture, handling, application of a mark [18], as well as the potential short-term and long-term harm related to the biopsy samples used in genetic tagging studies [19] [20].

This study documents the first evidence of movements and connectivity of bottlenose dolphins between the South Australian mainland and Kangaroo Island, based upon photo-identification data obtained from 3 separate studies carried out around South Australia.

\section{Methods}

Potential movements of bottlenose dolphins in South Australian waters were investigated through photo-identification techniques applied to dorsal fin images obtained from three distinct sites (Figure 1), which are representative of the

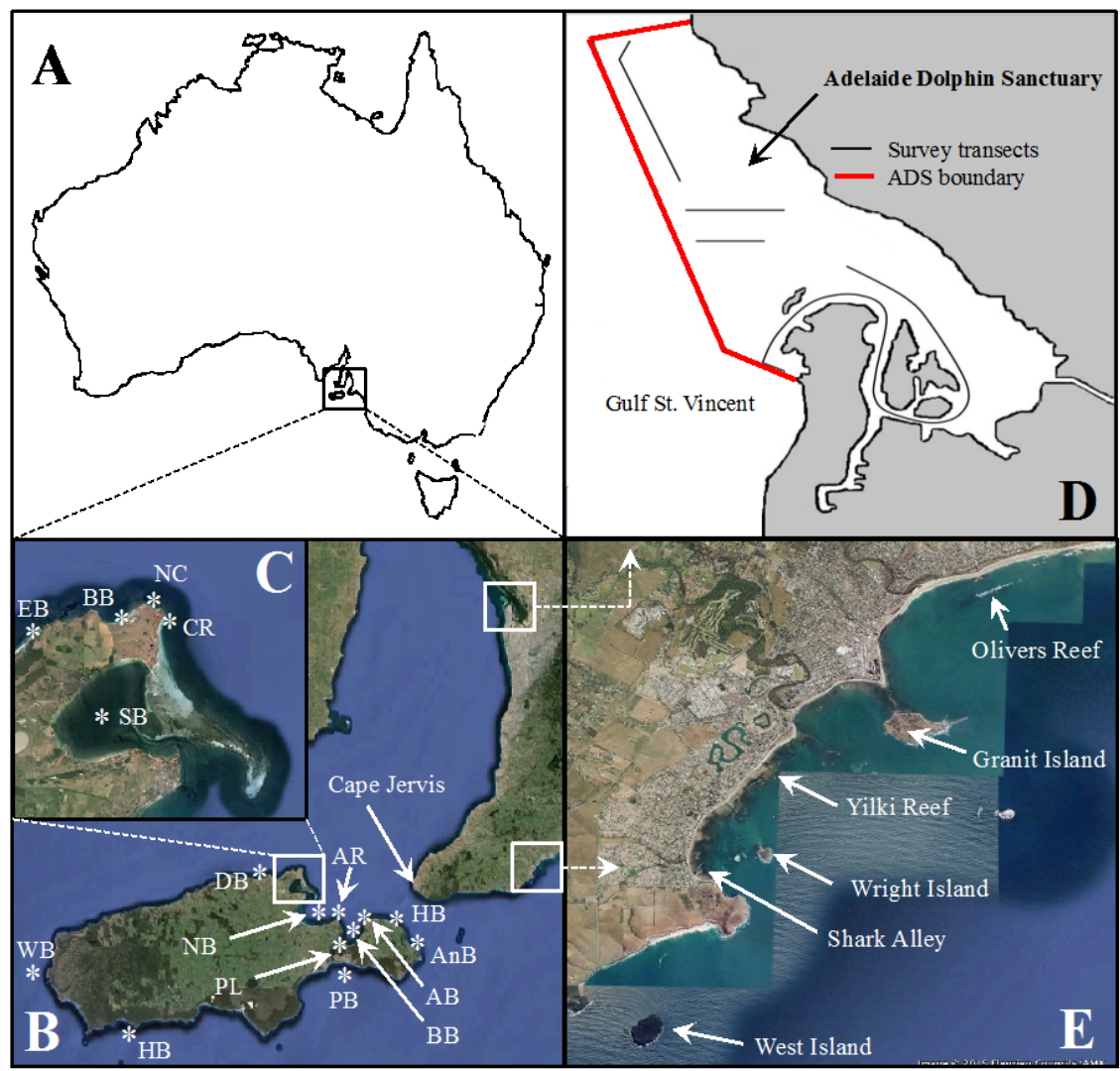

Figure 1. Location of the study area in South Australian waters (A) (B). Our study considered five sites in Kangaroo Island (B) (C), and two mainland locations, the southern Fleurieu Peninsula (B) (E) and the Adelaide Dolphin Sanctuary (D) that include respectively seven sites (one at Cape Jervis and six around Victor Harbor in Encounter Bay), and 4 survey transects. EB: Emu Bay, BB: Boxing Bay; CN: North Cape; CR: Cape Rouge; SB: Shoal Bay; NB: Nepean Bay; AR: American River; PL: Pelican Lagoon; BB: Browns Beach; AB: American Beach; HB: Hog Bay; AnB: Antechamber Bay; PB: Penington Bay; HB: Hanson Bay; WB: West Bay. The pictures shown in (B) $(C)$ and (E) were obtained through Google Earth. 
gradient of oceanographic conditions, hence the related variety of habitat types, encountered in South Australian waters.

Kangaroo Island is located at the edge of the South Australian continental shelf, and both its location and geometry shelter Gulf St. Vincent-a shallow (mean water depth $21 \mathrm{~m}$ ), low energy inverse estuary [21]-from the predominantly southwest swell generated by the Southern Ocean [22] [23] [24]. As such, Kangaroo Island is characterized by contrasted oceanographic conditions; its southern coasts are directly exposed to the Southern Ocean swell, while its northern shores are more similar to the sheltered conditions encountered in Gulf St. Vincent. The 16 stations considered in the coastal waters of Kangaroo Island were consistently characterized by soft benthic substrates consisting of a mosaic of bare sand and seagrass meadows.

Two mainland sites-the Port Adelaide River-Barker Inlet estuary and the southern Fleurieu Peninsula, including Cape Jervis on the west coast and Victor Harbor in Encounter Bay-were chosen for their distinct exposure to the open ocean. First, the Port Adelaide River-Barker Inlet estuary, where Tursiops spp. is a known resident [6] [25], is located on the north-eastern side of Gulf St. Vincent, $15 \mathrm{~km}$ north of the metropolitan city of Adelaide. This estuary, declared the Adelaide Dolphin Sanctuary (ADS) in 2005, with the intent to protect and conserve both the dolphins and their habitat covers $118 \mathrm{~km} 2$ of shallow waters (i.e. 0.5 to $17 \mathrm{~m}$; [4] [26]). Specifically, the southern area of the sanctuary is a sheltered water complex, fringed by mangrove forest, and dissected by numerous shallow bare sand channels [27]. In contrast, the northern area extending northwards out into the open waters of Gulf St. Vincent, is dominated by the presence of seagrass beds, predominantly Posidonia sp., Zostera sp. and Heterozostera spp. occur [28] [29]. Both of these habitat types represent important areas utilised by dolphins in this area [4]. Secondly, Victor Harbor is located on the western side of Encounter Bay, a large shallow and sheltered embayment where Southern right whales, Eubalaena australis, are recurrently observed forming aggregations [30]; both unaccompanied individuals and females typically return annually to these nearshore waters to give birth, raise young, and socialize [30] [31]. At Cape Jervis, and the 6 locations considered in Encounter Bay, the benthic substrates were consistently made of a mosaic of bare sand and seagrass meadows.

Photographs were taken over the period from 2005 to 2015, and dorsal fin images were maintained in three distinct catalogues according to each of the three study locations. These catalogues were used to identify individual dolphins from matches of distinctive dorsal fin features, such as nicks and notches present on both the trailing and leading edges of the fin and tip [16] [17]. Photographs were all taken using high resolution digital cameras and fin images were downloaded and sorted using either Windows Office Picture Manager or using Adobe Photoshop Elements imaging software. Images were analyzed using standard photo-identification methods [17] [32] and were graded according to their quality 
(i.e. excellent, average and poor) [33] [34]. Those photographs deemed excellent (e.g. fin angled parallel, sharp focus, no water droplets present, minimal glare and fin occupying a large proportion of the screen) were then used in the analysis. However, some photographs that were considered of average quality (i.e. those photographs of slightly lower resolution, but still providing a clear and non-ambiguous match of the animal) were occasionally deemed sufficient in order to provide a match and included. Poor quality photographs were always discarded from the analysis. Photographs from each of the 3 catalogues were then checked systematically against each other in order to assess whether animals had been resighted between locations and additionally to determine the number of resights of individuals. Individuals resighted in both locations were also additionally checked across a pre-existing catalogue from the ADS. Note that our photo-identification approach has specifically been chosen as it is cost-effective, can benefit from citizen science approaches and also has the great advantage of avoiding physical capture, handling, application of a mark [18], as well as the potential short-term and long-term harm related to the biopsy samples used in genetic tagging studies [19] [20].

\section{Results}

\subsection{Kangaroo Island}

Photo-identification surveys have been running from Kangaroo Island since the 30 November 2005. A total of 170 boat-based surveys have been conducted with dolphins having been sighted on 165 occasions. In total, 3518 dolphins were sighted, with 233 recognizable individuals catalogued. Among these individuals, $69(29.6 \%)$ were sighted on only one occasion, and $164(70.4 \%)$ on 2 or more occasions. Specifically, 33 were seen on 2 occasions (14.2\%) and 107 were sighted on 3 to 10 (45.9\%) occasions. Eighteen (7.7\%) individuals were sighted on 11 to 20 occasions and $6(2.6 \%)$ were sighted on 21 or more occasions.

\subsection{Fleurieu Peninsula}

Boat based surveys were initiated in the Southern Fleurieu Peninsula, including Cape Jervis and Encounter Bay on its east and west coasts on April 20, 2011 and have been ongoing since. To date 60 surveys have been completed, with dolphins sighted on 53 occasions. These surveys led to 654 dolphins sighted, with 74 recognizable dolphins catalogued. The resighting frequency is similar to Kangaroo Island, with 18 individuals (24.3\%) sighted on only one occasion, and 56 individuals $(75.7 \%)$ resighted on 2 or more occasions. Specifically, 13 individuals were seen on 2 occasions (17.6\%) and 30 were sighted on 3 to 10 (40.5\%) occasions. Ten individuals (13.5\%) were sighted on 11 - 20 occasions, and $3(4.1 \%)$ were sighted on 21 or more occasions.

\subsection{The Adelaide Dolphin Sanctuary}

Standardized boat-based surveys were conducted in the boundaries of the 
Adelaide Dolphin Sanctuary between the 6 March 2009 and 19 January 2011. In total 11 surveys were completed, with dolphins sighted on all 11 occasions. In total 181 dolphins were sighted over this period with 1039 images being taken and 487 deemed of excellent quality being used in the analysis. This resulted in 40 recognizable individuals being catalogued. These 40 individuals were sighted between 1 and 3 times. Only 14 (35\%) of the recognizable individuals were resighted, with 12 and 2 individuals seen on $2(30 \%)$ and $3(5 \%)$ occasions respectively. Overall 18 resightings (39\%) occurred over bare sand, and (61\%) over seagrass meadows.

\subsection{Resightings and Inter-Site Connectivity}

None of the bottlenose dolphins catalogued in the Adelaide Dolphin Sanctuary was resighted either in Kangaroo Island or in the Southern Fleurieu Peninsula. In contrast, 10 individuals were matched between the Kangaroo Island and Fleurieu Peninsula catalogues during the study period (Table 1). These resightings have consistently occurred from 2011 to 2015, and ranged between 1 and 7 (Table 1). Eight of these individuals were first seen in the coastal waters of the Fleurieu Peninsula, and resighted 1 to 4 times in various locations before being subsequently resighted in Kangaroo Island after a time-lag ranging from 6 days to 15 months (Table 1). Two of them were observed back in Kangaroo Islands 4 to 9 months after their last sighting in the Fleurieu Peninsula. Two individual was first sighted in Kangaroo Island, where it was resighted twice in nearly two years, before being resighted in the Fleurieu Peninsula 15 months later and making the trip back to Kangaroo Island in 6 days (Table 1 ).

\section{Discussion}

Our results provide the first evidence of connectivity between Tursiops spp.

Table 1. Summary of the movement patterns of the ten bottlenose dolphins resignted between Kangaroo Island and the Fleurieu Peninsulaas a function of their initial sighting $(\mathrm{S})$ and subsequent resightings $\left(\mathrm{RS}_{\mathrm{i}}\right)$ according to date $(\mathrm{D})$ and location $(\mathrm{L})$.

\begin{tabular}{|c|c|c|c|c|c|c|c|c|c|c|c|c|c|c|c|c|}
\hline \multirow[t]{2}{*}{$I D$} & \multicolumn{2}{|l|}{ S } & \multicolumn{2}{|c|}{$\mathrm{RS}_{1}$} & \multicolumn{2}{|l|}{$\mathrm{RS}_{2}$} & \multicolumn{2}{|c|}{$\mathrm{RS}_{3}$} & \multicolumn{2}{|c|}{$\mathrm{RS}_{4}$} & \multicolumn{2}{|c|}{$\mathrm{RS}_{5}$} & \multicolumn{2}{|l|}{$\mathrm{RS}_{6}$} & \multicolumn{2}{|l|}{$\mathrm{RS}_{7}$} \\
\hline & $\mathrm{D}$ & $\mathrm{L}$ & $\mathrm{D}$ & $\mathrm{L}$ & $\mathrm{D}$ & $\mathrm{L}$ & $\mathrm{D}$ & $\mathrm{L}$ & $\mathrm{D}$ & $\mathrm{L}$ & $\mathrm{D}$ & $\mathrm{L}$ & $\mathrm{D}$ & $\mathrm{L}$ & $\mathrm{D}$ & $\mathrm{L}$ \\
\hline 1 & $20 / 05 / 11$ & YR & $02 / 05 / 12$ & WI & $27 / 07 / 12$ & SA & $10 / 08 / 12$ & SA & $14 / 10 / 13$ & CR & $25 / 11 / 13$ & NC & $22 / 12 / 13$ & & $21 / 07 / 14$ & $\mathrm{NC}$ \\
\hline 2 & $02 / 05 / 12$ & WI & $21 / 12 / 12$ & OR & $14 / 01 / 13$ & YR & $27 / 03 / 13$ & YR & $08 / 10 / 13$ & YR & $05 / 06 / 14$ & $\mathrm{AB}$ & $08 / 03 / 15$ & & & \\
\hline 3 & $30 / 08 / 11$ & GI & $11 / 02 / 14$ & GI & $27 / 04 / 15$ & BB & & & & & & & & & & \\
\hline 4 & $12 / 11 / 12$ & YR & $21 / 12 / 12$ & OR & $14 / 01 / 13$ & YR & $08 / 06 / 13$ & WI & $08 / 10 / 13$ & YR & $05 / 06 / 14$ & $\mathrm{AB}$ & $15 / 10 / 14$ & & & \\
\hline 5 & $02 / 07 / 13$ & OR & $03 / 12 / 13$ & WTI & $30 / 03 / 15$ & NC & & & & & & & & & & \\
\hline 6 & $03 / 12 / 13$ & WTI & $08 / 12 / 14$ & $\mathrm{HB}$ & $22 / 02 / 15$ & $\mathrm{HB}$ & & & & & & & & & & \\
\hline 7 & $10 / 11 / 10$ & $\mathrm{HB}$ & $05 / 04 / 11$ & $\mathrm{BBH}$ & $29 / 01 / 12$ & $\mathrm{HB}$ & $06 / 03 / 13$ & $\mathrm{HB}$ & $17 / 04 / 13$ & $\mathrm{HB}$ & $11 / 03 / 14$ & $\mathrm{HB}$ & $31 / 05 / 14$ & & $05 / 06 / 14$ & $\mathrm{AB}$ \\
\hline 8 & $11 / 03 / 13$ & $\mathrm{HB}$ & $17 / 04 / 13$ & $\mathrm{HB}$ & $03 / 12 / 13$ & WI & & & & & & & & & & \\
\hline 9 & $31 / 05 / 14$ & $\mathrm{CJ}$ & $09 / 08 / 14$ & CJ & $05 / 06 / 14$ & $\mathrm{AB}$ & & & & & & & & & & \\
\hline 10 & $31 / 05 / 14$ & $\mathrm{CJ}$ & $05 / 06 / 14$ & $\mathrm{AB}$ & & & & & & & & & & & & \\
\hline
\end{tabular}

The Fleurieu Peninsula and Kangaroo Island observation site locations are respectively shown in blue and red; Yilki reef: YR; Wright Island: WI; Shark Alley, SA; Olivers Reef: OR; Granite Island: GI; West Island: WTI; Cape Jervis: CJ, Cape Rouge: CR; North Cape: NC; Boxing Bay: BB; Hog Bay: HB; Browns Beach: BBH; AB: Antechamber Bay. 
observed in the coastal waters of mainland South Australia and Kangaroo Island. These exchanges are, however, limited to the southern waters of the Fleurieu Peninsula and Kangaroo Island, as no match was found between the dolphins catalogued in the Adelaide Dolphin Sanctuary and either in Kangaroo Island or in the Fleurieu Peninsula.

These results suggest that (i) there is no latitudinal connectivity between the Tursiops spp. populations of the north (i.e. Adelaide Dolphin Sanctuary) and south (i.e. Kangaroo Island and southern Fleurieu Peninsula) waters of Gulf St. Vincent, and (ii) there are regular longitudinal cross-overs between Kangaroo Island and the southern Fleurieu Peninsula through Backstairs Passage for time scales ranging from a few days to 15 months. These results are consistent with previous results showing that the Adelaide Dolphin Sanctuary supports a small population of approximately 30 resident individuals-a figure compatible with the 40 recognizable individuals catalogued in the present work-as well as visiting non-regular transient animals [6] [25]. More specifically, these observations are also consistent with evidence that protected, shallow and narrow waterways which are geographically further from the open ocean such as the Adelaide Dolphin Sanctuary (see Figure 1(D)) generally promote limited movement patterns and therefore some degree of site fidelity [35] [36]. This is in contrast with open habitats where dolphins have more extensive home ranges and a lesser degree of site fidelity [35] [36]. In this context, a recent study conducted in the Adelaide Dolphin Sanctuary to assess potential habitat preference (i.e. bare sand vs. seagrass meadows) hypothesized that individuals resighted consistently over time in the bare sand habitat may hence potentially represent resident individuals, and therefore those sighted on fewer occasions in the seagrass habitat may be transients [4]. This hypothesis is consistent with the preference of the dolphins observed in Kangaroo Island and in the southern Fleurieu Peninsula for seagrass meadows. More generally, our observations are also congruent with studies conducted in the western Atlantic and Ireland [13] [37] that suggested that coastal stocks of bottlenose dolphins are comprised of residents (which are confined to certain areas) and transients (which migrate seasonally in and out of areas), which do not mix. These dolphins have also been reported to travel routinely back and forth between coastal locations, with movements occurring along narrow specific corridors close to shore [38], an observation consistent with the cross-overs observed between Kangaroo Island and the southern Fleurieu Peninsula. It is suggested however, that further, work investigating potential connectivity between the two southern study sites and the northern waters of the Adelaide would however be beneficial.

Potential exchanges between South Australian populations of bottlenose dolphins have previously been investigated across Spencer Gulf and coastal waters west of the gulf in the Great Australian Bight [39]. Using data from mitochondrial DNA control region sequences and 6 microsatellite loci, Bilgmann et al. [39] found marked genetic differentiation and low migration between bottlenose dolphins of the Spencer Gulf and those inhabiting coastal areas west of the gulf. 
These authors hypothesized that the restriction to dolphin gene flow is related to the oceanographic front that builds up at the mouth of Spencer Gulf over the austral summer due to strong differences in water temperature and salinity between surface and bottom waters that culminate in winter when the salty dense waters formed in the Spencer Gulf during summer cascade as a density current following winter cooling [40] [41]. In contrast to Spencer Gulf, vertical stratification (and density currents) rarely exist in Gulf St. Vincent where it is more horizontal [42] [43] due to the strong tidal flows (up to $1 \mathrm{~m} \cdot \mathrm{s}^{-1}$ ) occurring in Backstairs Passage that operate to destroy any vertical density stratification. Vertical stratification does, however, occur in northern Spencer Gulf, South of the swift tidal flows (i.e. up to $1 \mathrm{~m} \cdot \mathrm{s}^{-1}$; [44]) in Backstairs Passage that operate to destroy any vertical density stratification. Vertical stratification does occur, however, in the northern part of Gulf St. Vincent, south of the Port River-Barker Inlet estuary [45], and may hence represent a barrier to a southward dispersal of the bottlenose dolphin population of the Adelaide Dolphin Sanctuary. This hypothesis is consistent with previous evidence of both direct and indirect influence of oceanographic properties (e.g. temperature and salinity) on bottlenose dolphins. In the Black Sea, the distribution of bottlenose dolphin populations matched areas segregated by their oceanographic properties [46]. The distribution of coastal bottlenose dolphins may also be indirectly influenced by the effects physical oceanographic barriers such as fronts have on their prey distribution [47]. It is nevertheless noticeable that there is about an order of magnitude difference in the distance between Kangaroo Island and the Fleurieu Peninsula (ca. $12 \mathrm{~km}$ ) and the distance between Kangaroo Island and the Adelaide Dolphin Sanctuary (ca. $120 \mathrm{~km}$ ). Though these distances are both compatible with the home range previously reported for bottlenose dolphins T. truncatus and IndoPacific bottlenose dolphins T. aduncus in coastal and estuarine systems [20] [48], further work is needed to assess the effects of the interactions between distance, habitat, anthropogenic activities and oceanographic features in the connectivity of Tursiops populations in general, and in South Australian coastal waters in particular. Additional work is also needed to estimate the abundance of bottlenose dolphins in the coastal waters of the Kangaroo Island-Fleurieu Peninsula area to allow further comparisons with the recent estimates of the abundance of this species in Adelaide coastal waters that have recently been shown to range from 95 individuals in winter to 239 in summer. A comparison between the photo-identification catalogues obtained in the coastal waters of Adelaide [49] and Kangaroo Island-Fleurieu Peninsula [present study] would also represent a step forward in the understanding of the connectivity and residency of this species in South Australian waters.

This study demonstrates the ability of non-invasive and cost-effective techniques such as photo-identification as a reliable tool that can be used as a basis to design habitat studies, but also to study dolphin movement and population connectivity without using controversial tools based on live biopsy samples [20]. 
This issue is particularly critical in terms of management and conservation of South Australian bottlenose dolphins particularly as (i) the taxonomy of the species in South Australian waters is still debatable [50], and (ii) these waters are also increasingly threatened by a range of anthropogenic disturbances such as the development of desalination plants, fisheries, anthropogenic sound and oil and gas exploration; see e.g. [39] [51]. Specifically, genetic evidence, based on both mtDNA and microsatellite data, suggests that coastal bottlenose dolphins from South Australia, Victoria and Tasmania are evolutionarily distinct from the 2 other recognized bottlenose dolphin species [51]. As such, if some populations do not mix with other ones and others use specific migration corridors-as suggested by our results-the unique diversity of South Australian coastal waters and gulfs offer a rare opportunity to develop a more focused approach of the management and conservation of their bottlenose dolphin populations.

\section{Acknowledgements}

This research was financially supported under Australian Research Council's Discovery Projects funding scheme (projects number DP0664681 and DP0988554), Marine Innovation South Australia (MISA), the Department of Environment and Heritage and the Flinders Collaborative Research Grant Scheme (FCRGS) from the Faculty of Science and Engineering, Flinders University. Professor Seuront is the recipient of an Australian Professorial Fellowship (project number DP0988554).

\section{References}

[1] Leatherwood, S. and Reeves, R.R. (1983) The Sierra Club Handbook of Whales and Dolphins. Sierra Club Books, San Francisco.

[2] Kemper, C.M. and Ling, J.K. (1991) Whale Strandings in South Australia (1881-1989). Transactions of the Royal Society of South Australia, 115, 37-52.

[3] Kemper, C.M. (2004) Osteological Variation and Taxonomic Affinities of Bottlenose Dolphins, Tursiops spp., from South Australia. Australian Journal of Zoology, 52, 29-48. https://doi.org/10.1071/ZO03026

[4] Cribb, N., Miller, C. and Seuront, L. (2012) Indo-Pacific Bottlenose Dolphin (Tursiops aduncus) Habitat Preference in a Heterogeneous, Urban, Coastal Environment. Aquatic Biosystems, 9, 3. https://doi.org/10.1186/2046-9063-9-3

[5] Kemper, C.M., Harcourt, R., Gibbs, S., Miller, C. and Wright, A. (2006) Estimating Population Size of "at Risk" Bottlenose and Common Dolphins in Spencer Gulf and Gulf St. Vincent. South Australia. Consultancy report to Department of the Environment and Heritage, Canberra.

[6] Kemper, C.M., Bossley, M. and Shaughnessy, P. (2008) Marine Mammals of Gulf St Vincent and Investigator Straigh and Backstairs Passage. In: Shepherd, S., Bryars, S., Kirkegaard, I. and Harbison, P., Eds., Natural History of Gulf St. Vincent, Royal Society of South Australia, Adelaide, 339-352.

[7] Bilgmann, K., Möller, L.M., Harcourt, R.G., Gibbs, S.E. and Beheregaray, L.B. (2007) Genetic Differentiation in Bottlenose Dolphins from South Australia: Association with Local Oceanography and Coastal Geography. Marine Ecology Progress Series, 341, 265-276. https://doi.org/10.3354/meps341265 
[8] Robinson, K.P., O’Brien, J.M., Berrow, S.D., Cheney, B., Costa, M., Eisfeld, S.M., Haberlin, M.L., O’Donovan, M., Oudejans, M.G., Ryan, C., Stevick, P.T., Thompson, P.M. and Whooley, P. (2012) Discrete or Not So Discrete: Long Distance Movements by Coastal Bottlenose Dolphins in UK and Irish Waters. Journal of Cetacean Research and Management, 12, 365-371.

[9] Kemper, C.M. and Gibbs, S.E. (2001) Dolphin Interactions with Tuna Feedlots at Port Lincoln, South Australia and Recommendations for Minimising Entanglements. Journal of Cetacean Research and Management, 3, 283-292.

[10] Stevick, P.T., Palsboll, P.J., Smith, T.D., Bravington, M.V. and Hammond, P.S. (2001) Errors in Identification Using Natural Markings: Rates, Sources, and Effects on Capture-Recapture Estimates of Abundance. Canadian Journal of Fisheries and Aquatic Sciences, 58, 1861-1870.

[11] Katona, S.K. and Whitehead, H.P. (1981) Identifying Humpback Whales using Their Natural Markings. Polar Record, 20, 439-444. https://doi.org/10.1017/S003224740000365X

[12] Neumann, D.R., Leitenberger, A. and Orams, M.B. (2002) Photo-Identification of Short-Beaked Common Dolphins (Delphinusdelphis) in North-East New Zealand: A Photo-Catalogue of Recognisable Individuals. New Zealand Journal of Marine and Freshwater Research, 36, 593-604. https://doi.org/10.1080/00288330.2002.9517115

[13] O’Brien, J.M., Berrow, S.D., Ryan, C., McGrath, D., O’Connor, I., Pesante, G., Burrows, G., Massett, N. and Klötzer, W.P. (2010) A Note on Long-Distance Matches of Bottlenose Dolphins (Tursiops truncates) around the Irish Coast using Photo-Identification. Journal of Cetacean Research and Management, 11, 69-74.

[14] Laska, D., Speakman, T. and Fair, P.A. (2011) Community Overlap of Bottlenose Dolphins (Tursiopstruncatus) Found in Coastal Waters near Charleston, South Carolina. Journal of Marine Animals and Their Ecology, 4, 10-18.

[15] Tobena, M., Escánez, A., Rodríguez, Y., Lopez, C., Ritter, F. and Aguilar, N. (2004) Inter-Island Movements of Common Bottlenose Dolphins Tursiopstruncatus among the Canary Islands: Online Catalogues and Implications for Conservation and Management. African Journal of Marine Science, 36, 137-141. https://doi.org/10.2989/1814232X.2013.873738

[16] Wursig, B. and Wursig, M. (1977) The Photographic Determination of Group Size, Composition and Stability of Coastal Porpoises (Tursiops truncatus). Science, 198, 755-756. https://doi.org/10.1126/science.198.4318.755

[17] Wursig, B. and Jefferson, T.A. (1990) Methods of Photo-Identification for Small Cetaceans. In: Hammond, P.S., Mizroch, S.A., Donovan, G.P., Eds., Individual Recognition of Cetaceans. Use of Photo-Identification and Other Techniques to Estimate Population Parameters, Reports of the International Whaling Commission, Special Issue 12, Cambridge, 43-52.

[18] Perrin, W.F., Wursig, B. and Thewissen, J.G.M. (2002) Marine Mammal Encyclopaedia. 2nd Edition, Academic Press.

[19] Kiszka, J., Simon-Bouhet, B., Charlier, F., Pusineri, C. and Ridoux, V. (2010) Individual and Group Behavioural Reactions of Small Delphinids to Remote Biopsy Sampling. Animal Welfare, 411-417.

[20] Noren, D.P. and Mocklin, J.A. (2012) Review of Cetacean Biopsy Techniques: Factors Contributing to Successful Sample Collection and Physiological and Behavioral Impacts. Marine Mammal Science, 28, 154-199.

https://doi.org/10.1111/j.1748-7692.2011.00469.x 
[21] Käempf, J. (2014) South Australia's Large Inverse Estuaries: On the Road to Ruin, Estuaries of Australia in 2050 and beyond. Springer Netherlands, 153-166. https://doi.org/10.1007/978-94-007-7019-5_9

[22] Fuller, M.K., Bone, Y., Gostin, V.A. and Von Der Borch, C.C. (1994) Holocene Cool-Water Carbonate and Terrigenous Sediments from Southern Spencer Gulf, South Australia. Journal of the Geological Society of Australia, 41, 353-363.

[23] Harris, P.T. (1994) Comparison of Tropical, Carbonate and Temperate, Siliciclastic Tidally Dominated Sedimentary Deposits: Examples from the Australian Continental Shelf. Journal of the Geological Society of Australia, 41, 241-254.

[24] Porter-Smith, R., Harris, P.T., Andersen, O.B., Coleman, R., Greeslade, D. and Jenkins, C.J. (2004) Classification of the Australian Continental Shelf Based on Predicted Sediment Threshold Exceedance from Tidal Currents and Swell Waves. Marine Geology, 211, 1-20.

[25] Steiner, A. and Bossley, M. (2008) Some Reproductive Parameters of an Estuarine Population of Indo-Pacific Bottlenose Dolphins (Tursiops aduncus). Marine Mammal Science, 2, 34-63.

[26] Cribb, N., Miller, C. and Seuront, L. (2008) Assessment of Bottlenose Dolphin (Tursiops aduncus) Habitat Characteristics in the Estuarine Waters of the Adelaide Dolphin Sanctuary, South Australia. The Journal of Marine Animals and Their Ecology, 1, 1-3.

[27] Jones, G.K., Baker, J.L., Edyvane, K. and Wright, G.J. (1996) Nearshore Fish Community of the Port River-Barker Inlet Estuary, South Australia. I. Effect of Thermal Effluent on Fish Community Structure, and Distribution and Growth of Economically Important Fish Species. Marine and Freshwater Research, 47, 785-799. https://doi.org/10.1071/MF9960785

[28] Connolly, R.M. (1994) A Comparison of Fish Assemblages from Seagrass and Unvegetated Areas of a Southern Australian Estuary. Australian Journal of Marine and Freshwater Research, 45, 1033-1044. https://doi.org/10.1071/MF9941033

[29] Bloomfield, A.L. and Gillanders, B.M. (2005) Fish and Invertebrate Assemblages in Seagrass, Mangrove, Saltmarsh and Non-Vegetated Habitats. Estuaries, 28, 63-77. https://doi.org/10.1007/BF02732754

[30] Burnell, S.R. and Bryden, M.M. (1997) Coastal Residence Periods and Reproductive Timing in Southern Right Whales, Eubalaena australis. Journal of Zoology, London, 241, 613-621. https://doi.org/10.1111/j.1469-7998.1997.tb05736.x

[31] Carroll, E.L., Rayment, W.J., Alexander, A.M., Baker, C.S., Patenaude, N.J., Steel, D., Constatine, R., Cole, R., Boren, L.J. and Childerhouse, S. (2014) Reestablishment of Former Wintering Grounds by New Zealand Southern Right Whales. Marine Mammal Science, 30, 206-220. https://doi.org/10.1111/mms.12031

[32] Mazzoil, M., McCulloch, S.D., Defran, R.H. and Murdoch, M.E. (2004) Use of Digital Photography and Analysis of Dorsal Fins for Photo-Identification of Bottlenose Dolphins. Aquatic Mammals, 30, 209-219.

https://doi.org/10.1578/AM.30.2.2004.209

[33] Baird, R.W., Webster, D.L., Mahaffy, S.D., McSweeney, D.J., Schorr, G.S. and Ligon, A.D. (2008) Site Fidelity and Association Patterns of in a Deep-Water Dolphin: Rough-Toothed Dolphins (Steno bredanensis) in the Hawaiian Archipelago. Marine Mammal Science, 24, 535-553. https://doi.org/10.1111/j.1748-7692.2008.00201.x

[34] Baird, R.W., Gorgone, A.M., McSweeney, D.J., Ligon, A.D., Deakos, M.H., Webster, D.L., Schorr, G.S., Martien, K.K., Salden, D.R. and Mahaffy, S.D. (2009) Population Structure of Island-Associated Dolphins: Evidence from Photo-Identification of 
Common Bottlenose Dolphins (Tursiops truncatus) in the Main Hawaiian Islands. Marine Mammal Science, 25, 251-274. https://doi.org/10.1111/j.1748-7692.2008.00257.x

[35] Defran, R.H. and Weller, D.W. (1999) Occurrence, Distribution, Site Fidelity and School Size of Bottlenose Dolphins (Tursiops truncatus) off San Diego, California. Marine Mammal Science, 15, 366-380. https://doi.org/10.1111/j.1748-7692.1999.tb00807.x

[36] Gubbins, C. (2002) Use of Home Ranges by Resident Bottlenose Dolphins (Tursiops truncatus) in a South Carolina Estuary. Journal of Mammalogy, 83, 178-187. https://doi.org/10.1644/1545-1542(2002)083<0178:UOHRBR>2.0.CO;2

[37] Scott, G.P., Burn, D.M. and Hansen, L.J. (1988) The Dolphin Die Off: Long-Term Effects and Recovery of the Population. Proceedings of the Oceans ' 88 Conference, IEEE Cat. No. 88-CH2585-8, Vol. 3, 819-823.

[38] Defran, R.H., Caldwell, M., Morteo, E., Long, A.R., Rice, M.G. and Weller, D.W. (2015) Possible Stock Structure of Coastal Bottlenose Dolphins of Baja California and California Revealed by Photo-Identification Research. Bulletin, Southern California Academy of Sciences, 114, 1-11. https://doi.org/10.3160/0038-3872-114.1.1

[39] Bilgmann, K., Parra, G.J., Zanardo, N., Beheregaray, L.B. and Möller, L.M. (2014) Multiple Management Units of Short-Beaked Common Dolphins Subject to Fisheries Bycatch off Southern and Southern Australia. Marine Ecology Progress Series, 500, 265-279. https://doi.org/10.3354/meps10649

[40] Lennon, G.W., Bowers, D.G., Nunes, R.A., Scott, B.D., Ali, A., Boyle, J., Wenju, C., Herzfeld, M., Johansson, G., Nield, S., Petrusevics, P., Stephenson, P., Suskin, A.A. and Wijffels, S.E.A. (1987) Gravity Currents and the Release of Salt from an Inverse Estuary. Nature, 327, 695-697. https://doi.org/10.1038/327695a0

[41] Petrusevics, P.M. (1993) SST Fronts in Inverse Estuaries, South Australia-Indicators of Reduced Gulf-Shelf Exchange. Australian Journal of Marine and Freshwater Research, 44, 305-323. https://doi.org/10.1071/MF9930305

[42] Bye JAT (1976) Physical Oceanography of Gulf St. Vincent and Investigator Strait. In: Twidale, C.R., Ed., Natural History of the Adelaide Region, Royal Society of South Australia, 143.

[43] De Silva Samarasinghe, J.R. and Lennon, G.W. (1987) Hypersalinity, Flushing and Transientsalt-Wedges in a Tidal Gulf-An Inverse Estuary. Estuarine Coastal Shelf Science, 24, 483-498.

[44] Noye, B.J. and Grzechnik, M. (1995) Tides and Currents of Gulf St. Vincent, South Australia. Proceedings of the Ocean and Atmosphere Pacific International Conference, Adelaide, 23-27 October 1995, 253-258.

[45] Kaempf, J. (2006) In Situ Field Measurements for Adelaide Coastal Waters Study-Final Technical Report. ACWS Technical Report No. 7 Prepared for the Adelaide Coastal Waters Study Steering Committee. School of Chemistry, Physics and Earth Sciences, Flinders University of SA, Adelaide.

[46] Natoli, A., Birkun, A., Aguilar, A., Lopez, A. and Hoelzel, A.R. (2005) Habitat Structure and the Dispersal of Male and Female Bottlenose Dolphins (Tursiops truncatus). Proceedings of the Royal Society of London B, 272, 1217-1226. https://doi.org/10.1098/rspb.2005.3076

[47] Dowling, T.E. and Brown, W.M. (1993) Population Structure of the Bottlenose Dolphin) as Determined by Restriction Endonuclease Analysis of Mitochondrial DNA. Marine Mammal Science, 9, 138-155.

https://doi.org/10.1111/j.1748-7692.1993.tb00439.x 
[48] Sprogis, K.R., Raudion, H.C., Rankin, R., MacLeod, C.D. and Bejder, L. (2016) Home Range Size of Adult Indo-Pacific Bottlenose Dolphins (Tursiops aduncus) in a Coastal and Estuarine System Is Habitat and Sex-Specific. Marine Mammla Science, 32, 287-308. https://doi.org/10.1111/mms.12260

[49] Zanardo, N., Parra, G. and Möller, L.M. (2016) Site Fidelity, Residency, and Abundance of Bottlenose Dolphins (Tursiops sp.) in Adelaide's Coastal Waters, South Australia. Marine Mammal Science, 32, 1381-1401.

https://doi.org/10.1111/mms.12335

[50] Charlton-Robb, K., Gershwin, L.A., Thompson, R., Austin, J., Owen, K. and McKenchie, S. (2011) A New Dolphin Species, the Burrunan Dolphin Tursiops australis sp. nov., Endemic to Southern Australian Costal Waters. PLoS ONE, 6, e24047. https://doi.org/10.1371/journal.pone.0024047

[51] Käempf, J. and Clarke, B. (2013) How Robust Is the Environmental Impact Assessment Process in South Australia? Behind the Scenes of the Adelaide Seawater Desalination Project. Marine Policy, 38, 500-506. 